\title{
DIVERGÊNCIA GENÉTICA ENTRE DOZE GENÓTIPOS DE ABACAXIZEIRO (Ananas comosus L, Merril.) ESTIMADA POR ANÁLISE DE MARCADORES RAPD ${ }^{1}$
}

\author{
CÍCERO DONIZETE PEREIRA² \& WARWICK ESTEVAM KERR ${ }^{3}$
}

\begin{abstract}
RESUMO - Por meio de estudos moleculares, este trabalho determinou a distância genética entre 12 genótipos de $A$. comosus por marcadores RAPD (Random Amplified Polymorphic DNA), utilizando 11 "primers" decâmeros da OPERON Technologies Inc. Dos 12 genótipos , 1 foi proveniente da Jamaica, 2 do Estado do Acre (Quinari e RBR-1), 2 do Estado do Maranhão (Turiaçu e São Domingos), 3 do Estado do Piaú (Cefas, Floriano-1 e Floriano-2), 2 do Estado da Bahia (Monte Alegre-1 e Monte Alegre-2) e 2 de Minas Gerais (Pérola e Smouth Cayenne). Pela análise de "cluster", utilizando o método de UPGMA, foi constatada uma grande divergência entre os genótipos de $A$. comosus estudados com a separação destes em dois grupos a uma distância genética de $31,1 \%$.
\end{abstract}

Termos para indexação: Biologia molecular, Caracterização molecular.

\section{GENETIC DIVERGENCE AMONG TWELVE GENOTYPES OF PINEAPLE (Ananas comosus L, Merril.) ESTIMATED BY RAPD MARKERS}

\begin{abstract}
Through molecular studies, the genetic distance among 12 genotypes of A. comosus for RAPD markers (Random Amplified Polymorphic DNA) was determined using 11 primers (decamers) of the OPERON Technologies Inc. From the 12 genotypes, 1 came from Jamaica, 2 from the State of Acre (Quinari and RBR-1), 2 from the State of Maranhão (Turiaçu and São Domigos), 3 the State of Piauí (Cefas, Floriano-1 and Floriano-2), 2 from the State of Bahia (Monte Alegre-1 and Monte Alegre-2) and 2 from Minas Gerais (Pérola and Smooth Cayenne). By the analysis of cluster, using the method of UPGMA, a great divergence was verified among the genotypes of $A$. comosus studied or tima separation in two groups of a genetic distance of $31,1 \%$.
\end{abstract}

Index terms: Molecular biology, Molecular chacterization.

\section{INTRODUÇÃO}

O Brasil tem uma expressiva participação na produção mundial de abacaxi, estando entre os três primeiros produtores. A cultura ocupa aproximadamente 50000 ha, destacando-se o Estado de Minas Gerais, primeiro produtor, seguido pelos Estados do Pará, Paraíba, Bahia, São Paulo e Espírito Santo (Agrianual, 2000). Em Minas Gerais, o Triângulo Mineiro é responsável por $92 \%$ da produção do Estado (Couto, 1982).

O comércio mundial de abacaxi in natura atingiu 700 mil toneladas, e o comércio de abacaxi transformado em suco ou conserva é equivalente a 4 milhões de toneladas de frutas frescas (Agrianual, 2000).

$\mathrm{Na}$ bibliografia, estudos moleculares sobre o abacaxizeiro, ganhou um valioso espaço nos últimos anos. A bromelina, uma protease sulfídrica presente nesta espécie, é, talvez, o enfoque científico mais estudado. Isto se dá pela importância desta proteína na farmacologia, onde foi registrada sua interferência no crescimento de células malignas, inibição de coágulos, atividade fibrinolítica e ação antiinflamatória (Taussig \& Batkin, 1998). Estudos com marcadores moleculares ligados a doenças, pragas ou mesmo estudos de divergência genética ainda são pouco encontrados na literatura sobre abacaxi.
A técnica de RAPD, uma das derivações da PCR, trouxe uma melhoria acentuada à técnica por utilizar iniciadores (primers) curtos e de seqüências arbitrárias como um método de geração de marcadores moleculares polimórficos, não exigindo assim o conhecimento prévio de seqüências do DNA a ser estudado (Welsh \& Mcclelland, 1990). Esta técnica abre uma nova perspectiva para a análise genômica de indivíduos e populações (Chalmers et al., 1992; Howell et al., 1994; Ferreira \& Grattapaglia,1998;)

Vários trabalhos mostraram que a técnica RAPD foi eficiente na caracterização, identificação, estudos de filogenia, análise genômica, identificação de marcadores moleculares ligados a genes de interesse e estudos de composição genômica (Stiles et al., 1993; Young \& Kelly 1996; Fang et al., 1997; Hu et al., 1997).

Ruas et al. (1995) citaram a importância das estimativas da relação e da diversidade genética de cultivares de abacaxizeiro para avaliação de recursos genéticos. Estes autores encontraram uma relação genética bastante similar entre quatro cultivares de abacaxizeiro (Pérola, Smooth Cayenne, Primavera e Perolera) e compatibilidade dos resultados obtidos por meio de marcadores moleculares RAPD e análises das características morfológicas e

\footnotetext{
1 Trabalho $n^{0}$ 178/2000. Recebido: 14/08/2000. Aceito para publicação: 03/05/2001. (Trabalho 178/2000).

2 Universidade Federal de Uberlândia - Instituto de Genética e Bioquímica - Laboratório de Genética - Campus Umuarama, Bloco 2E - CEP 38400-902 - Uberlândia, MG - cdpereira@ufu.br

3 Instituto Nacional de Pesquisa da Amazônia, INPA - Av. André Araújo 2936 - Petrópolis - Caixa Postal 478 - CEP 69083-000 - Manaus/AM warwick@inpa.gov.br
} 
agronômicas, mostrando que a análise por RAPD pode ser usada de maneira eficiente para caracterização de recursos genéticos no gênero Ananas.

Duval et al. (1999), por meio da utilização de enzimas de restrição, estudaram o parentesco filogenético de uma coleção de 96 acessos de Ananas utilizando DNA cloroplástico. Os resultados mostraram variações entre o gênero Ananas e Pseudananas em regiões de cpDNA, sem, no entanto, sugerir uma nova divisão dentro do gênero estudado.

Este trabalho teve como objetivo determinar a distância genética entre doze cultivares de abacaxi por meio da técnica de RAPD.

\section{MATERIAL E MÉTODOS}

O experimento foi conduzido no Laboratório de Genética do Instituto de Genética e Bioquímica da Universidade Federal de Uberlândia, no período de janeiro/1997 a fevereiro/1999.

Os abacaxizeiros utilizados neste experimento foram coletados no Brasil (Acre, Maranhão, Piauí, Bahia, Minas Gerais) e Jamaica (Tabela 1). Os abacaxizeiros provenientes do Acre foram coletados no banco de germoplasma da EMBRAPA/AC; os do Maranhão, Bahia e Minas Gerais foram coletados em lavouras comerciais de suas respectivas regiões e os do Piauí foram coletados numa pequena coleção do CEFAS (Centro Educacional São Francisco de Assis). Todos os abacaxizeiros obtidos foram plantados na área experimental da Universidade Federal de Uberlândia.

TABELA 1- Genótipos de abacaxizeiros (Ananas comosus L. Merril) e seus respectivos locais de coleta de 1993 a 1997. Uberlândia (MG), 1999.

\begin{tabular}{ll}
\hline Local de Coleta & Cultivar (es) \\
\hline Jamaica & Jamaicano* \\
Acre & Quinari, RBR-1 \\
Maranhão & Turiaçu*, São Domingos* \\
Piauí & Cefas*, Floriano-1*, Floriano-2* \\
Bahia & Monte Algre-1, Monte Alegre-2* \\
Minas Gerais & Pérola, Smooth Cayenne (Havaiano) \\
\hline
\end{tabular}

* Nome da cultivar arbitrário de acordo com o local de coleta

Também foram coletadas duas outras espécies do mesmo gênero (A. ananassoides e A. nanus) para serem avaliadas juntamente com os abacaxizeiros (A comosus).

Para extração de DNA, foi coletada uma folha jovem (a mais interna e clorofilada da roseta) de cada indivíduo. Destas folhas, após serem bem lavadas com detergente e água, foram utilizados $300 \mathrm{mg}$ cortados em pequenos pedaços, para se extrair o DNA.

O protocolo utilizado para extração foi o proposto por Ferreira \& Gratapaglia et al. (1998), com algumas modificações. Inicialmente, $300 \mathrm{mg}$ de folha fresca foram maceradas na presença de nitrogênio líquido e transferidas para um tubo de 2 ml. Sobre cada extrato, foi adicionado $1,5 \mathrm{ml}$ de tampão de extração (Polivinilpirrolidone a 2\%; $\mathrm{NaCl} 1,4 \mathrm{M}$; Tris $\mathrm{HCl}$ pH $8,0100 \mathrm{mM}$; EDTA $20 \mathrm{mM}$; CTAB a $2 \%$; $\beta$-Mercaptoetanol a $0,2 \%$ ) e incubado em banho-maria a $65^{\circ} \mathrm{C}$ por uma hora com posterior centrifugação a $11300 \mathrm{~g}$ por 10 minutos. O sobrenadante obtido foi transferido para um novo tubo e adicionado $4 \mu \mathrm{lde}$
RNAase (10 ng/ $\mu \mathrm{l})$, incubando o extrato vegetal por 30 minutos a $37^{\circ} \mathrm{C}$. Em seguida, completou-se o volume do tubo com Clorofórmio:Álcool Isoamílico (24:1) e centrifugou-se por 10 minutos a $11300 \mathrm{~g}$. O sobrenadante foi coletado procedendo-se mais uma vez a extração com Clorofórmio:Álcool Isoamílico. O DNA foi precipitado adicionando-se ao sobrenadante $2 / 3$ do volume de Isopropanol absoluto PA e 1/10 do volume de Acetado de Sódio $3 \mathrm{M}$. Após permanecer durante a noite a $4^{\circ} \mathrm{C}$, os tubos foram centrifugados a $11300 \mathrm{~g}$ por 15 minutos e o DNA ("pellet") lavado com etanol a 70\%. Depois, o DNA foi seco em estufa a $37^{\circ} \mathrm{C}$ e ressuspendido em $100 \mu \mathrm{l}$ de Tris-EDTA (TE) - DNA estoque.

De 119 primers testados, 11 foram selecionados para estudos de divergência genética por serem mais informativos (Tabela 2). Todos os primers utilizados foram fabricados pela OPERON Technologies Inc. sendo todos oligonucleotídeos com 10 bases e de seqüências arbitrárias.

TABELA 2- Primers arbitrários utilizados e suas respectivas seqüências de nucleotídeos. Uberlândia (MG), 1999.

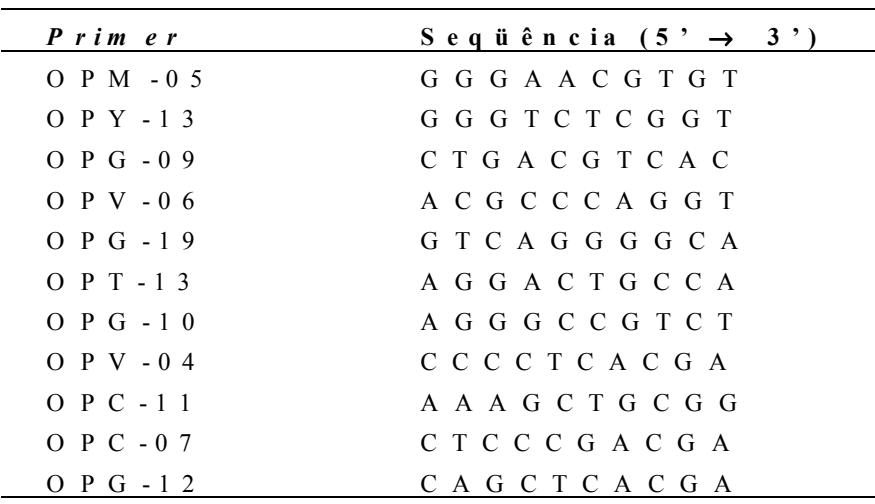

O volume total de cada reação foi de $20 \mu$. Cada reação continha Tris- $\mathrm{HCl} 10 \mathrm{mM}, \mathrm{KCl} 50 \mathrm{mM}, \mathrm{MgCl}_{2} 2 \mathrm{mM}, 400 \mu \mathrm{M}$ de dNTPs $(100 \mu \mathrm{M}$ de dGTP, $100 \mu \mathrm{M}$ de dCTP, $100 \mu \mathrm{M}$ de dATP e $100 \mu \mathrm{M}$ de dTTP), 8 pmoles de primer, 1,0 U de Taq DNA Polimerase, 15 ng de DNA genômico (ausente no controle negativo feito para cada bateria de reações) e água ultrapura para completar o volume de $20 \mu 1$. Em cada reação, foi adicionada uma gota de óleo mineral para evitar a evaporação. Antes de ir para o termociclador, cada reação foi submetida a um pulso de $1810 \mathrm{~g}$.

Para cada bateria de reações, foi feito um controle negativo com todos os compostos da reação exceto o DNA, para confirmar se os produtos amplificados das reações representavam DNA genômico amplificado, contaminações ou artefatos do primer.

As reações foram amplificadas em termociclador $\mathrm{MJ}$ Research, Inc., modelo PTC-100, por 3 ciclos de $94^{\circ} \mathrm{C} / 1 \mathrm{~min}$, $35^{\circ} \mathrm{C} / 1 \mathrm{~min}$ e $72^{\circ} \mathrm{C} / 2 \mathrm{~min} ; 34$ ciclos de $94^{\circ} \mathrm{C} / 10 \mathrm{~s}, 40^{\circ} \mathrm{C} / 20 \mathrm{~s}$, $72^{\circ} \mathrm{C} / 2 \mathrm{~min}$, conforme descrito por Young \& Kelly (1996).

Para cada primer, foram realizadas no mínimo duas reações para confirmar o padrão de banda obtido, conforme descrito por Oliveira (1998).

Os produtos amplificados foram separados em gel de agarose $1,5 \%$ de $20 \mathrm{~cm} \times 24,5 \mathrm{~cm} \times 6 \mathrm{~mm}$ em Tampão Tris-BoratoEDTA (TBE) 0,5X, de acordo com Sambrook et al. (1989). A visualização dos produtos amplificados foi feita em luz 
ultravioleta por meio do corante Brometo de Etídio, diluído no gel, numa concentração aproximada de $0,5 \mu \mathrm{g} / \mathrm{ml}$ de gel.

Para a eletroforese, foram adicionados em cada amostra (15 $\mu$ l) $3 \mu \mathrm{l}$ de um tampão de carregamento (Azul de bromofenol 3,61M, Xileno Cianol 4,64M, Sacarose 1,17M e EDTA 0,1M $\mathrm{pH} 8,0)$. A eletroforese foi conduzida a $0,23 \mathrm{~V} / \mathrm{ml}$ por 2 horas. Os géis foram visualizados em transiluminador UV e fotografados em VDS Image System - Pharmacia, usando filtro laranja e com tempo de exposição 2,17 segundos, contraste de 0 a 6 , e 0,45 de fator de correção da câmera.

Para análise dos dados, foi montada uma matriz binária de acordo com presença (1) e ausência de (0) bandas reproduzíveis e mais intensas. A matriz gerada pelo programa STATISTICA 4,5A (1993) foi usada para o cálculo das distâncias genéticas e análise de agrupamento. As distâncias genéticas foram calculadas pelo método de Porcentagem de Desacordo, que é dado pela fórmula: $\mathrm{N}_{\mathrm{AB}}{ } / \mathrm{N}_{\mathrm{T}}$, onde $\mathrm{N}_{\mathrm{AB}}$ é o número total de bandas polimórficas entre os genótipos comparados e $\mathrm{N}_{\mathrm{T}}$ é o número total de bandas.

A análise de grupos ou "clusters" foi feita pelo método não ponderado de agrupamento aos pares, utilizando médias aritméticas (UPGMA - "Unweighted pair-group method using arithmetic average"), o qual agrupa indivíduos de acordo com a similaridade. Sendo que os indivíduos mais similares são agrupados inicialmente e assim, sucessivamente, até os indivíduos ou grupos mais distantes.

\section{RESULTADOS E DISCUSSÃO}

Para aumentar a eficiência na identificação de polimorfismo, os 11 primers decâmeros utilizados foram selecionados de 119, de acordo com o maior número de bandas geradas e a melhor definição dos produtos amplificados. Estes 11 primers geraram 79 regiões polimórficas em 12 genótipos de abacaxizeiro. Estas bandas apresentaram tamanhos estimados na faixa de 200 a $2700 \mathrm{pb}$.

Para cada primer, foram realizadas duas ou mais repetições, sendo computadas apenas as bandas que mostraram boa repetibilidade e intensidade. Estes cuidados na montagem da matriz reduzem a possibilidade de eventuais erros na contagem incorreta de produtos fracamente amplificados que não correspondam à verdadeira história evolutiva da espécie (Lowe et al., 1996; Cabral, 1997; Oliveira, 1998).

A Figura 1 exemplifica um bom padrão de amplificação obtido nas repetições para os doze genótipos analisados, como também mostra o tamanho-padrão dos fragmentos amplificados pela técnica de RAPD que é de fragmentos entre 400 e 1500pb (Ferreira \& Grattapaglia, 1998).

A Figura 2 mostra a análise de agrupamento baseada na Porcentagem de Desacordo utilizando o método UPGMA. Ao nível de $40 \%$ de divergência, as espécies do gênero Ananas foram separadas, conforme esperado, sendo A. anassoides e A. nanus agrupadas, demonstrando entre os dois últimos um grau de semelhança maior do que algumas variedades dentro de $A$. comosus. Ao nível de $31,1 \%$ de distância genética, houve a definição de dois grupos para a população de $A$. comosus. O grupo A, com distância genética variando de $6,7 \%$ a $28,9 \%$, foi constituído de 7 genótipos, entre os quais o São Domingos,
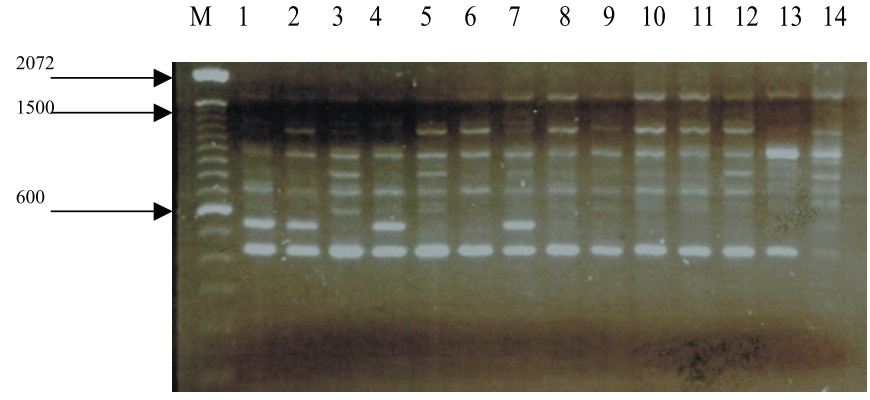

FIGURA 1. Padrão de amplificação de fragmentos de DNA obtido com o primer OPG-19 para 12 genótipos de abacaxizeiros, onde (M) DNA Marcador de 100 pb, (1) São Domingos, (2) RBR-1, (3) Jamaica, (4) Pérola, (5) Havaiano, (6) Turiaçu, (7) Quinari, (8) Monte Alegre-1, (9) Monte Alegre-2, (10) CEFAS, (11) Floriano-1, (12) Floriano-2, (13) $A$. ananassoides, (14) A. nanus. Uberlândia (MG), 1999.

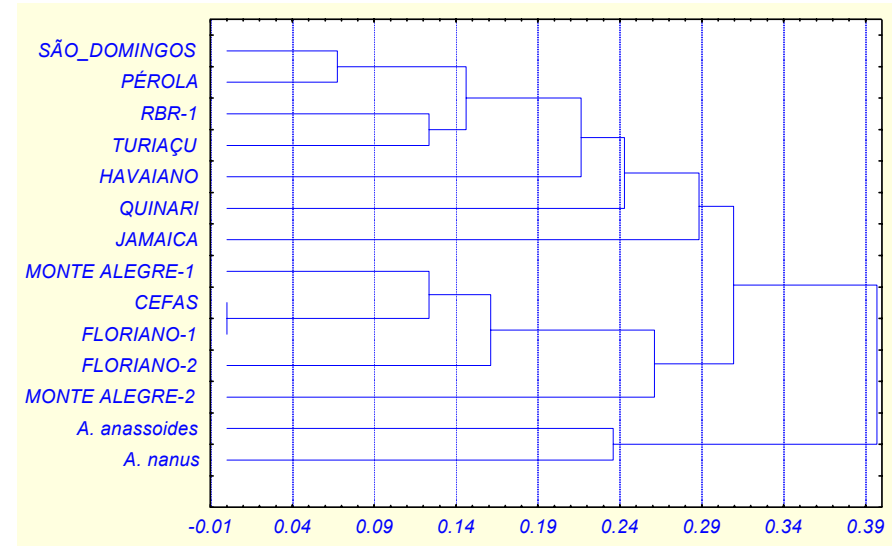

FIGURA 2- Dendograma em porcentagem de desacordo, representando distâncias genéticas entre 12 genótipos de abacaxizeiro gerados por 79 marcadores RAPD, utilizando o método de UPGMA. Uberlândia (MG), 1999.

Pérola, RBR-1, Turiaçu, Smouth Cayenne, Quinari e Jamaica. O grupo $\mathrm{B}$, com a distância genética entre os genótipos variando de $0 \%$ a $26,1 \%$, ficou representado por 5 genótipos: Monte Alegre-1, CEFAS, Floriano-1, Floriano-2 e Monte Alegre-2. Ananas anassoides e A. nanus apresentaram-se como "outgroup". Estas duas espécies, apesar de as suas características fenotípicas serem bastante similares ao $A$. comosus e de se cruzarem com esta espécie (Kinjo, 1993), apresentaram uma distância genética de $39,7 \%$ em relação ao abacaxizeiro comum. Os dados moleculares confirmam a classificação taxonômica dessas espécies. No entanto, estudos com RAPD com maior número de primers e estudos da viabilidade dos híbridos entre estas espécies deveriam ser feitos para comprovar ou não a classificação taxonômica atual (Oliveira, 1998; Skelton, 1996).

Os genótipos CEFAS e Floriano-1 são molecularmente idênticos. Isto confirmou a eficiência da técnica RAPD para estudos de distâncias genéticas, já que estes genótipos são derivados de propagação vegetativa de um mesmo abacaxizeiro, sendo assim clones (Ruas et al., 1995).

A proximidade entre os genótipos Pérola e São 
Domingos, bastante similares fenotipicamente, e a divergência entre os genótipos Havaiano e Quinari, também bastante similares fenotipicamente, mostraram a não-correlação entre a caracterização fenotípica e a caracterização molecular.

\section{CONCLUSÕES}

1 - A uma distância genética de $31,1 \%$, houve a separação dos genótipos de Ananas comosus em dois grupos.

2 - Não foi encontrada divergência entre CEFAS e Floriano-2 com os 11 primers testados, reforçando a hipótese de que estes materiais são originários de um mesmo abacaxizeiro por meio de propagação vegetativa.

3 - Ananas anassoides e A. nanus divergiram de A. comosus a $39,7 \%$.

4 - A técnica RAPD mostrou-se eficiente para o cálculo da divergência genética.

5 - Agrupamento por análise molécular nem sempre coincide com semelhanças fenotípicas.

\section{AGRADECIMENTOS}

Os autores agradecem ao $\mathrm{CNPq}$ - Conselho Nacional de Desenvolvimento Científico e Tecnológico; ao pesquisador José Renato Santos Cabral - CNPMF/EMBRAPA; aos Engenheiros Agrônomos José Roberto Silva (EMATER - Monte Alegre de Minas) e José Alberto Leitão (EMATER - Frutal).

\section{REFERÊNCIAS BIBLIOGRÁFICAS}

AGRIANUAL: Anuário da agricultura brasileira. São Paulo: FNP Consultório e Comércio, 1999, 521 p.

CABRAL, T. A. T. 1997. Divergência genética entre genótipos de algodoeiro (Gossypium hirsutum L.) estimada por análise de marcadores RAPD. 1997. 47f. Dissertação (Mestrado em Genética e Bioquímica) - Instituto de Genética e Bioquímica, Universidade Federal de Uberlândia, Uberlândia, 1997

CHALMERS, K. J.; WAUGH, R.; SPRENT, J. I.; SIMOM, A. J.; POWELL, W. 1992. Detection of genetic variation between and Within populations of Gliricidia sepium and G. maculata using RAPD markers. Heredity, Oxford, v. 69, p. 465-472, 1992.

COUTO, F. A. D. A cultura do abacaxizeiro em Frutal e Monte Alegre de Minas. Boletim Téenico, Belo Horizonte; v. 15, p. 120, 1982.

DUVAL, M. F.; BUSO, G. S. C.; CABRAL, J. R.; BIANCHETTI, L. de B.; FERREIRA, F. R.; FERREIRA, M.E. Phylogenetic relationships in Ananas and other related genera using chloroplast DNA restriction site variation. Genetics and Molecular Biology, Ribeirão Preto, v. 22, n. 3, supplement, p. 502, 1999.

FANG, D. Q.; FEDERICI, C. T.; ROOSE, M. L. Development of molecular markers linked to a gene controlling fruit acidity in citrus. Genome, Ottawa, v. 40, p. 841-849, 1997.
FERREIRA, M.E., GRATTAPAGLIA, D.. Introdução ao uso de marcadores moleculares em análise genética. 3. ed. , Brasília: EMBRAPA/CENARGEN, 1998, 220p.

HOWELL, E. C; NEWBURY, H. J.; SWENNEM, R. L.; WITHERS, L. A.; FORD-LLOYD,B.V. The use of RAPD for identifying and classifying musa germplasm. Genome, Ottawa, v.37, p. 328-332, 1994.

HU, S. Y.; OHM, H. W.; DWEIKAT, I. Identification of RAPD marders linked to the gene PM1 for resistance to powdery mildew in wheat. Theoretical and Applied Genetics, Berlin, v. 94, p. 832-840, 1997.

KINJO, K. Inheritance of leaf margin spine in pineapple. Acta Horticulturae, Wageningem, v. 334, p. 59-66, 1993.

LOWE, A. J.; HANOTTE, O.; GUARINO, L. Standardization of molecular genetic technique for the characterization of germplasm collections: The case of random amplified polymorphic DNA (RAPD). FAO, p. 50-54, 1996.

OLIVEIRA, R. C. Divergência genética por marcadores RAPD em Tetragonisca angustula Latreille, 1811 (Hymenoptera, Apidae, Meliponinae). Uberlândia, 1998. 50f. Dissertação (Mestrado em Genética e Bioquímica) - Instituto de Genética e Bioquímica, Universidade Federal de Uberlândia, Uberlândia, 1998.

RUAS, P. M.; RUAS, C. F.; FAIRBANDS, J. D.; ANDERSEN, R. W.; CABRAL, J. R. S. Genetic relatonship among four varieties of pineapple, Ananas comosus, revealed by random amplified polymorphic DNA (RAPD) analysis. Brazilian Journal of Genetics, Ribeirão Preto, v. 18, n. 3, p. 413 - 416, 1995.

SAMBROOK, J.; FRITSCH, E. F.; MANIATIS, T. Molecular Cloning: A Laboratory Manual 1. 2. ed. New York: Cold Spring Harbor Laboratory Press, 1989. 608p.

SKELTON, P. Evolution - a biological and palaentological approach. Wokingham - England, 1996. 1064 p.

STILES, J. I.; LEMME, C; SONDUR, S.; MORSHIDI, M. B.; MANSHARDT, R. Theoretical and Applied Genetics, Berlin, v. 85, p. $697-701,1993$.

TAUSSIG, S. J.; BATKIN, S. Bromelain, the enzyme complex of pineapple (Ananas comosus) and its clinical application. Jounal Ethnofharmacology, Limerick, v. 22, n.2, p. 191-203, 1998.

WELSH, J.; MACCLELLAND, M. Fingerprinting genomes using PCR with arbitrary primers. Nucleic Acids Research, Oxford, v. 18, p. 7213-7218, 1990.

YOUNG, R. A.; KELLY, J. D. RAPD markers finding the Are gene for anthracnose resistance in common bean. Journal of the American Hortscience, Alexandria, v. 121, n. 1, p. 37-41, 1996. 